\title{
Effectiveness of Graptophyllum pictum (L.) Griff leaf extraction on blood glucose level in alloxan-induced Wistar rat
}

\author{
${ }^{1}$ Leonoreza, A., ${ }^{1}$ Excelinda, T., ${ }^{1}$ Elnitiarta, J., ${ }^{2}$ Heri-Nugroho, H.S., ${ }^{3}$ Hendrianingtyas, M. \\ and ${ }^{3} *$ Retnoningrum, D. \\ ${ }^{1}$ Department of Medicine, Faculty of Medicine, Diponegoro University, Jalan Prof. H. Soedarto, SH, \\ Tembalang, Semarang, Jawa Tengah, Indonesia 50275 \\ ${ }^{2}$ Department of Internal Medicine, Faculty of Medicine, Diponegoro University, Jalan Prof. H. Soedarto, \\ SH, Tembalang, Semarang, Jawa Tengah, Indonesia 50275 \\ ${ }^{3}$ Department of Clinical Pathology, Faculty of Medicine, Diponegoro University, Jalan Prof. H. Soedarto, \\ SH, Tembalang, Semarang, Jawa Tengah, Indonesia 50275
}

\author{
Article history: \\ Received: 29 December 2019 \\ Received in revised form: 1 \\ March 2020 \\ Accepted: 3 March 2020 \\ Available Online: 30 May \\ 2020
}

\section{Keywords:}

Graptophyllum pictum (L.)

Griff,

Blood glucose,

Diabetes mellitus

\section{DOI:}

https://doi.org/10.26656/fr.2017.4(S3).S12

\begin{abstract}
Diabetes mellitus is a metabolic disease that always increasing in prevalence. Excessive glucose intake and oxidative stress that can lead to damage to the pancreatic cell or insulin resistance, are such factors that influence the occurrence of diabetes mellitus. Graptophyllum pictum (L.) Griff leaf contains active metabolites such as flavonoid which able to decrease free radical levels. This study aimed to prove the effectiveness of Graptophyllum pictum (L.) Griff leaves extract on blood glucose levels in alloxan-induced Wistar rats. In this study, twenty-five male Wistar rats were divided into five groups. On day 0 , the negative control and each treatment group injected with $125 \mathrm{mg} / \mathrm{kg}$ dose of alloxan and would be checked on $4^{\text {th }}$ day. On the $4^{\text {th }}$ day after the rats had diabetes, normal group (K-1) was given only standard feed, Negative control (K-2) was given only alloxan intraperitoneally on day 0 , first treatment group (K-3) was given $50 \mathrm{mg} / \mathrm{kg}$ dose of Graptophyllum pictum (L.) Griff, second treatment group (K-4) was given $100 \mathrm{mg} / \mathrm{kg}$ dose of the leaf extract, and the third treatment group (K-5) was given the leaf $200 \mathrm{mg} / \mathrm{kg}$ dose of the leaf extract. On the $10^{\text {th }}$ day, fasting blood glucose was taken from the rats. Post-test only group design was used to be the experimental design. There were significant differences in the treatment groups (K-3, K-4, and K-5) compared to the negative control group (K-2) after treatment. The mean of blood glucose levels decreased with the increased doses of Graptophyllum pictum (L.) Griff leaf extract treatment. The treatment groups (K-3, K-4, and K-5) were not significant compared to the normal group (K-1).
\end{abstract}

\section{Introduction}

Diabetes mellitus is symptoms that arise in a person caused by an increase in blood glucose levels due to a progressive decrease in insulin secretion (American Diabetes Association, 2015). Diabetes can be divided into two groups based on insulin requirements, namely insulin-dependent diabetes mellitus (IDDM/insulindependent diabetes mellitus or type 1) and insulindependent diabetes mellitus (NIDDM/non-insulin dependent diabetes mellitus or type 2) (Mycek et al., 2013). Riskesdas (2018) showed that the prevalence of the population of $\geq 15$ years old in Indonesia is increased from $1.5 \%$ to $2.0 \%$.

Therapy for diabetes mellitus can be divided into pharmacological and non-pharmacological therapies (Wells et al, 2009), both of which aim to control blood glucose levels and prevent complications (Chang et al., 2013). Non-pharmacological therapy is a regular diet and exercise regulation. Whereas pharmacological therapy includes the administration of insulin and oral antidiabetic drugs (Wells et al, 2009). Although many antidiabetic drugs have been proven to be effective, herbal medicines are still in great demand because of their fewer side effects and naturally derived (Chandrashekharaiah, 2013). At present more than 400 species of plants have been used as alternative treatments for diabetes, although only a few have been scientifically studied (Patel et al., 2012). Some plants have been studied and have anti-diabetic activity, one of which is 
the Graptophyllum pictum (L.) Griff leaves. Graptophyllum pictum (L.) Griff leaves have been used by the community in healing various diseases, such as hemorrhoids, ulcers, ulceration of the ears and stomach, and facilitating menstrual cycles for women (Dalimartha, 1999). In addition, Graptophyllum pictum (L.) Griff leaves also contain flavonoids which have the ability to bind reactive oxygen species (Murugesu et al., 2017) and alkaloids that have the possibility to cure various diseases related to blood glucose (Bharti et al., 2018).

Utilization of Graptophyllum pictum (L.) Griff leaf among the community is still impressed by trial and error and there is still no precise formulation and clear use of Graptophyllum pictum (L.) Griff leaf, either as an external medicine or medicine that is consumed. Therefore, research on anti-diabetic activity of Graptophyllum pictum (L.) is needed. Graptophyllum pictum (L.) Griff, is a member of the Acanthaceae family, has also been empirically used as a traditional antidiabetic drug in Indonesia. The aim of this research was to prove the effectiveness of Graptophyllum pictum (L.) Griff leaves extract on blood glucose levels in alloxan-induced Wistar rats.

\section{Materials and methods}

The materials used in this study were Graptophyllum pictum (L.) Griff leaves, distilled water, 70\% ethanol, male Wistar rats weighing 200-300 g, alloxan, salt solution $(0.9 \% \mathrm{NaCl}$ solution $)$, filter paper. The tools used in this study were glass funnels, stainless steel vessels, water baths, analytical scales, porcelain cups, flacons, $1.0 \mathrm{~mL}$ injection syringes, $3.0 \mathrm{~mL}, 5 \mathrm{~mL}$, and 18 -gauge oral syringes.

This was an experimental study with post-test only control group design. The sample for this study were male Wistar rats. The sample size for this study was in accordance with the World Health Organization (WHO) criteria, which was a minimum of five rats per treatment group. The inclusion criteria of this study were Wistar strain male white rats aged 2-3 months, body weight 150-250 g, in a state of hyperglycemia (fasting blood glucose level $\geq 135 \mathrm{mg} / \mathrm{dL}$ ) after induced by alloxan, healthy and active moving rat. Exclusion criteria were Wistar rat that was sick or died during treatment. The samples of this study were twenty-five acclimated rats for 7 days. Rats were randomized into five groups namely normal group $(\mathrm{K}-1)$, negative control $(\mathrm{K}-2)$, first treatment group (K-3), second treatment group (K-4), and third treatment group (K-5).

\section{Results}

Table 1 shows the mean blood glucose in treatment 1
(K-3) approached the value of blood glucose in the normal group (K-1) when compared to other groups. In treatment group 3 (K-5) blood glucose results were obtained with an average of $55.60 \mathrm{mg} / \mathrm{dL}$ which were at risk of hypoglycemia because based on Wolfenshon and Lloyd (2013), the normal blood glucose was $50-135 \mathrm{mg} /$ dL. One-way ANOVA test on Table 1 shows significant differences in all groups $(\mathrm{p}=0.001)$. A significant different was found between normal group and negative control group $(\mathrm{p}=0.001)$ and all treatment group with negative control group. No significant difference between treatment and normal group. The $\mathrm{p}$ value among groups can be seen on Table 2 .

Table 1. Blood glucose levels in all groups

\begin{tabular}{lcc}
\hline Group & Mean $\pm \mathrm{SD}(\mathrm{g} / \mathrm{dL})$ & $\mathrm{p}$-value \\
\hline Normal group (K-1) & $81.60 \pm 3.68$ & \\
Negative control (K-2) & $333.80 \pm 6.35$ & \\
Treatment group 1 (K-3) & $72.00 \pm 5.93$ & $0.001^{*}$ \\
Treatment group 2 (K-4) & $70.20 \pm 1.24$ & \\
Treatment group 3 (K-5) & $55.60 \pm 4.89$ & \\
\hline
\end{tabular}

*One-way ANOVA

Table 2. Comparison of blood glucose levels between groups

\begin{tabular}{|c|c|c|c|c|}
\hline Group & 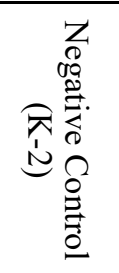 & 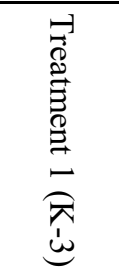 & 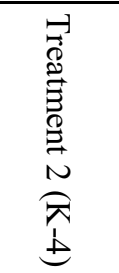 & 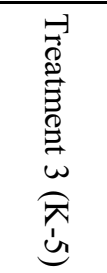 \\
\hline Normal group (K-1) & $0.001 *$ & 0.823 & 0.79 & 0.546 \\
\hline Negative control (K-2) & - & $0.001 *$ & $0.001 *$ & $0.001 *$ \\
\hline Treatment group $1(\mathrm{~K}-3)$ & & - & 0.963 & 0.676 \\
\hline Treatment group 2 (K-4) & & & - & 0.71 \\
\hline Treatment group $3(\mathrm{~K}-5)$ & & & & - \\
\hline
\end{tabular}

*Post Hoc LSD

\section{Discussion}

Based on the data analysis, significant results were obtained in the negative control group (K-2) compared with the treatment group with $\mathrm{p}$-value $>0.05$. No significant results were obtained between the treatment groups. The average glucose level in the treatment group decreased with increasing dose of the Graptophyllum pictum (L.) Griff leaves, although statistically, it showed no significant results between the treatment groups. The most effective dose of Graptophyllum pictum (L.) Griff leaf extract was $50 \mathrm{mg} / \mathrm{kg}$ because the blood glucose level in the group of rats was close to the normal group mean value of rats (Sasmita et al., 2017).

The decrease in glucose levels in the treatment group was influenced by the presence of flavonoids, alkaloids, saponins, and tannins on Graptophyllum pictum (L.) Griff leaves. This active ingredient in extract acts as an 
antioxidant to prevent pancreatic $\beta$-cell damage from getting worse. Flavonoids have an ortho-dihydroxy (cathecol) structure in ring B which is important in reactive oxygen species (ROS) binding activity. The structure donates hydrogen ions and electrons to hydroxyl radicals, hydroperoxyl and peroxynitrite to make these radicals in a stable condition (Sarian et al., 2017). Alkaloids stimulate the hypothalamus to increase the secretion of Growth Hormone Releasing Hormone, resulting in an increase in Growth Hormone secretion in the pituitary. High GH levels can stimulate the liver to secrete Insulin-like Growth Factor-1 (IGF-1) which can induce hypoglycemia and reduce gluconeogenesis activity resulting in decreased glucose levels and insulin requirements (Rahmi, 2014). Saponin in Solanum anguivi fruit can work as a free radical scavenger and has reducing effect and iron-chelating ability in the treatment of diseases where ROS is involved (Barky and Hussein, 2017). In addition, tannin acts as antioxidants (Kumari and Jain, 2015) and disrupt the activity of glycolytic enzymes such as phosphoenolpyruvate carboxykinase. The enzyme phosphoenolpyruvate carboxykinase plays a role in the conversion of oxaloacetate to phosphoenolpyruvate. Disruption of this enzyme causes the inhibition of glycolysis process and glucose output will be reduced (Aba and Asuzu, 2018).

Several previous studies using plant extracts containing flavonoids and alkaloids showed significant results. The previous study about the effects of flavonoids of lavender leaves can reduce the blood glucose levels in rats (Sasmita et al., 2017). Larantukan et al. (2014) regarding extracts of Moringa skin stem that contain alkaloids can reduce blood glucose levels in rats (Larantukan et al., 2014). The rats induced by alloxan in this research had a different effect of duration to be hyperglycemia. For that reason, initial treatment of extract feeding was different in every rat. This condition may cause pancreatic islet healing if the researcher waiting all of the rats had hyperglycemia and giving them treatment in one time, considering alloxan induce diabetes in the rats reversibly. For anticipating this, the extract feeding was equally given for 10 days after the rat hyperglycemia.

\section{Conclusion}

Graptophyllum pictum (L.) Griff leaves extract treatment at a dose of 50,100 , and $200 \mathrm{mg} / \mathrm{kg}$ orally can reduce blood glucose levels significantly compared with negative controls. The extract at the $50 \mathrm{mg} / \mathrm{kg}$ was the closest blood glucose level to normal group (K-1). Based on the experiment, the $50 \mathrm{mg} / \mathrm{kg}$ body weight dose was the best compared to other groups.

\section{Conflict of interest}

The authors declare no conflict of interest regarding the publication of this paper.

\section{Acknowledgments}

The authors are grateful to the Indonesian Ministry of Research, Technology, and Higher Education for financial assistance. This work was supported by grants from "Program Kreativitas Mahasiswa".

\section{References}

Aba, P.E. and Asuzu, I.U. (2018). Mechanisms of Actions of Some Bioactive Anti-Diabetic Principles from Phytochemicals of Medicinal Plants: A Review. Indian Journal of Natural Products and Resources, 9(2), 85-96.

American Diabetes Association. (2015). Introduction. Diabetes Care, 38(Suppl. 1), S1-S2. https:// doi.org/10.2337/dc15-S001

Barky, A.E. and Hussein, S.A. (2017). Saponins and Their Potential Role in Diabetes Mellitus. Diabetes Management, 7(1), 148-158.

Bharti, S.K., Krishnan, S., Kumar, A. and Kumar, A. (2018). Antidiabetic phytoconstituents and their mode of action on metabolic pathways. Therapeutic Advances in Endocrinology and Metabolism Review, 9(3), $\quad 81-100 . \quad$ https:// doi.org/10.1177/2042018818755019

Chandrashekharaiah, K.S. (2013). Antioxidant and type II diabetes-related enzyme inhibit on properties of few selected medicinal plants. Biomedical and Pharmacology Journal, 6(2), 341-347. https:// doi.org/10.13005/bpj/423

Chang, C.L.T., Lin, Y., Bartolome, A.P., Chen, Y., Chiu, S. and Yang, W. (2013). Herbal Therapies for Type 2 Diabetes Mellitus: Chemistry, Biology, and Potential Application of Selected Plants and Compounds. Evidence-Based Complementary and Alternative Medicine, 2013, 1-33. https:// doi.org/10.1155/2013/378657

Dalimartha, S. (1999). Atlas Tumbuhan Obat Indonesia Jilid I. Jakarta: Trubus Agriwidya. [In Bahasa Indoensia].

Kementerian Kesehatan. (2018). Hasil Utama Riskesdas Tentang Prevalensi Diabetes Mellitus di Indonesia 2018. Retrieved from website: https:// www.kemkes.go.id/resources/download/info-terkini/ hasil-riskesdas-2018.pdf

Kumari, M. and Jain, S. (2012). Tannin : An Antinutrient with Positive Effect to Manage Diabetes Tannins: An Antinutrient with Positive Effect to Manage Diabetes. Research Journal of Recent Sciences, 1 
(12), 1-8.

Larantukan, S.V.M, Setiasih, N.L.E. and Widyastuti, S.K. (2014). Pemberian Ekstrak Etanol Kulit Batang Kelor Glukosa Darah Tikus Hiperglikemia. Indonesia Medicus Veterinus, 3(4), 292-299.

Mycek, M.J., Harvey, R.A. and Champe, P.C. (2013). Farmakologi Ulasan Bergambar. 4th ed. Jakarta: Widya Medika.

Patel, D.K., Prasad, S.K., Kumar, R. and Hemalatha, S. (2012). An overview on antidiabetic medicinal plants having insulin mimetic property. Asian Pacific Journal of Tropical Biomedicine, 2(4), 320-330. https://doi.org/10.1016/S2221-1691(12)60032-X

Rahmi, H. (2014). Aktivitas Ekstrak Daun Wungu (Graptophyllum pictum (L.) Griff) Dalam Menurunkan Glukosa Darah Pada Tikus Hiperglikemia. Bogor: Institut Pertanian Bogor, MSc. Thesis. [In Bahasa Indonesia].

Sarian, M.N., Ahmed, Q.U., Mat-So'ad, S.Z., Alhassan, A.M., Murugesu, S., Perumal, V., Syed Mohamad, S.N.A., Khatib, A. and Latip, J. (2017). Antioxidant and Antidiabetic Effects of Flavonoids: A StructureActivity Relationship Based Study. BioMed Research International, 2017, 1-14. https:// doi.org/10.1155/2017/8386065

Sasmita, F.W., Susetyarini, E. and Pantiwati, Y. (2017). Efek Ekstrak Daun Kembang Bulan (Tithonia diversifolia) terhadap Kadar Glukosa Darah Tikus Wistar (Rattus norvegicus) yang Diinduksi Alloxan. Biosfera, 34(1), 22-31. https:// doi.org/10.20884/1.mib.2017.34.1.412

Wells, B., Dipiro, J.T., Schwinghammer, T. and Dipiro, C.V. (Ed.). (2009). Pharmacotherapy handbook. $7^{\text {th }}$ ed. New York: The McGraw-Hill Companies. 